\title{
Spinal Epidermoid Cyst Formation After Spinal Fracture Operation: A Case Report
}

\author{
Spinal Kurk Ameliyatundan Sonra Spinal Epidermoid Kist: \\ Bir Olgu Sunumu
}

\author{
Han-Song SHENG, Jian LIN, Huai-Ou WANG, Bo YIN, Nu ZHANG \\ 2nd Affiliated Hospital of Wenzhou Medical College, Department of Neurosurgery, Wenzhou, China
}

Corresponding Author: Nu ZHANG / E-mail: wzneurosurgery@hotmail.com

\begin{abstract}
Acquired spinal epidermoid cysts are extremely rare. There are only a few reports on the formation of epidermoid cysts after lumbar puncture or spinal trauma. In this report, we present a patient who was diagnosed with epidermoid cyst after operation for spinal fracture. This 43-yearold female suffered from progressively worsening low back pain radiating down the left leg four years after lumbar burst fracture in the L1 segment and subsequent posterior vertebral pedicle screw fixation surgery. 1 year later, the spinal fracture fixation devices were successfully removed. On admission, spinal magnetic resonance imaging found a cyst locating anterior to the site of operation and this lesion was removed by a following total laminectomy. To the best of our knowledge, this is the first case ever reported showing the formation of epidermoid cyst after primary spinal fracture operation. Therefore, in patients with a history of spinal fracture operation, spinal epidermoid cysts should be taken into consideration if the low back pain and radiculopathy were refractory.
\end{abstract}

KEYWORDS: Epidermoid cyst, Lumbar spine fracture, Laminectomy

öz

Akkiz spinal epidermal kistler çok nadirdir. Lumber ponksiyon veya spinal travma sonrasında epidermoid kist oluşumuyla ilgili sadece birkaç rapor vardır. Bu raporda, spinal kırık ameliyatı sonrasında epidermoid kist tanısı konan bir hastayı sunuyoruz. Bu 43 yaşında kadın L1 segmentinde lumber burst kırığı ve posterior vertebral pedikül vidası fiksasyon cerrahisinden dört yıl sonra sol bacakta aşağıya doğru yayılan ve giderek artan bel ağrısından yakınıyordu. Spinal kırık fiksasyon cihazları ameliyattan 1 yıl sonra başarıyla çıkarılmıştı. Yattığında spinal manyetik rezonans görüntüleme ameliyat bölgesine anterior bir kist gösterdi ve bu lezyon total laminektomi ile çıkarıldı. Bildiğimiz kadarıyla bu vaka primer spinal kırık ameliyatından sonra epidermoid kist oluşumu bildirilen ilk vakadır. Bu nedenle spinal kırık ameliyatı öyküsü olan hastalarda refrakter bel ağrısı ve radikülopati mevcutsa spinal epidermoid kist olasılığı dikkate alınmalıdır.

ANAHTAR SÖZCÜKLER: Epidermoid kist, Lumber omurga kırığı, Laminektomi

\section{INTRODUCTION}

Epidermoid cyst accounts for less than $1.0 \%$ of all intracranial tumors and its presence is even rarer in the spinal canal. Besides, epidermoid cyst can either be congenital or acquired and, among which, acquired spinal epidermoid tumors are in the extremely rare category $(8,10)$. In most cases, acquired spinal epidermoid tumors are reported to result from inadvertent transplantation of epithelial tissue into the thecal sac during lumbar puncture $(6,9,11)$. There are also a few reports on trauma related epidermoid cyst $(2,4)$. However, as far as we know, this is the first case report on the formation of epidermoid cyst after spinal fracture operation.

\section{CASE REPORT}

A 43-year old female was referred to our hospital complaining about progressively aggravating back pain radiating down left leg for 3 months. The pain mainly occurred at night and was is intensified by coughing and forward bending movement. The patient can only raise her left leg to about $50^{\circ}$ in the Laseque's Test. The deep tendon reflexes were normal. Four years ago, she had lumbar burst fracture at the L1. A detailed physical examination showed the patient had no neurologic deficits after the injury and she received posterior vertebral pedicle screw fixation surgery (Figure $1 A, B$ ). During operation, a laceration of the dura resulting from the burst fractures was found and repaired. One year after the first operation, the implanted spinal fracture fixation devices were removed by a secondary surgery (Figure 1C). The patient lived a normal life without evidence of neurological deficit for the last three years. However, after admission this time, magnetic resonance imaging (MRI) of the lumbar spine demonstrated an intradural lesion at the level of $L 1$ vertebrae, just anterior to the site of previously operation. This mass was isointensive on T1-weighted images and hyperintensive on T2-weighted images (Figure 2A, B). No enhancement was found in contrastenhanced T1-weighted images after the administration of gadolinium (Figure 2C). A subsequent total L1 laminectomy 


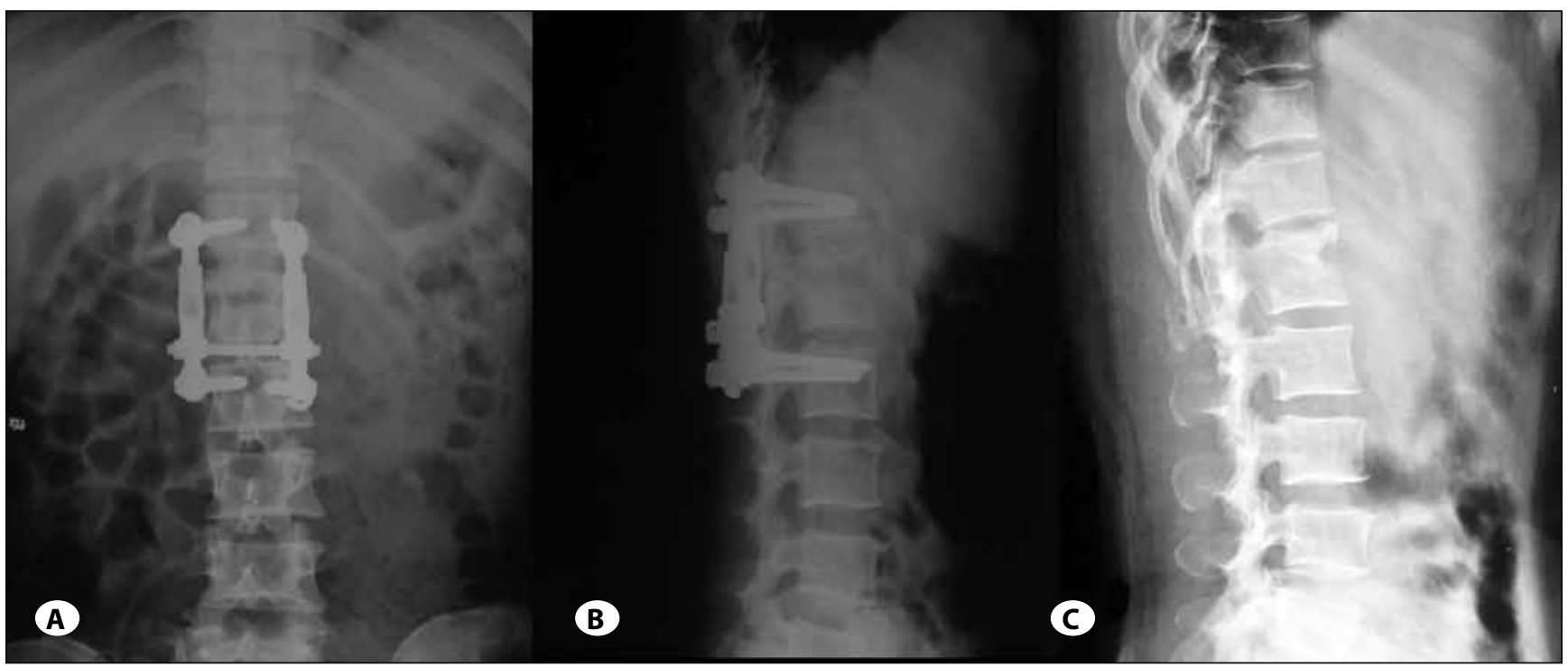

Figure 1: Plain films of the spine: antero-posterior (A) and lateral (B) view showed that posterior vertebral pedicle fixation devices were successfully implanted. 1 year later, another plain film in lateral view (C) showed the internal implantations were successfully removed.

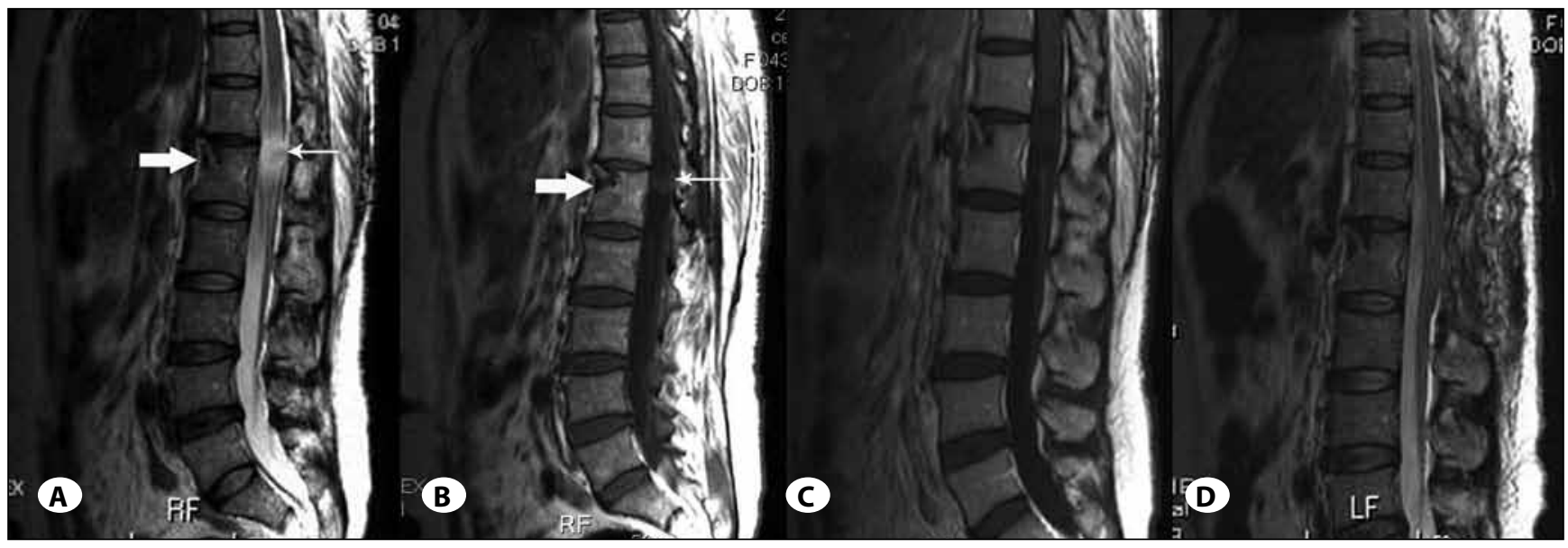

Figure 2: Spinal MR images: T2-weighted (A) and T1 weighted (B) sagittal image showed a hyperintense intradural extramedullary cauda equina mass lesion at L1 (small arrow) and a sequela of fracture (big arrow). The mass had no contrast enhancement following gadolinium injectionin T1 weighted image (C). Postoperative T2-weighted sagittal image showed that the cyst was completely removed (D).

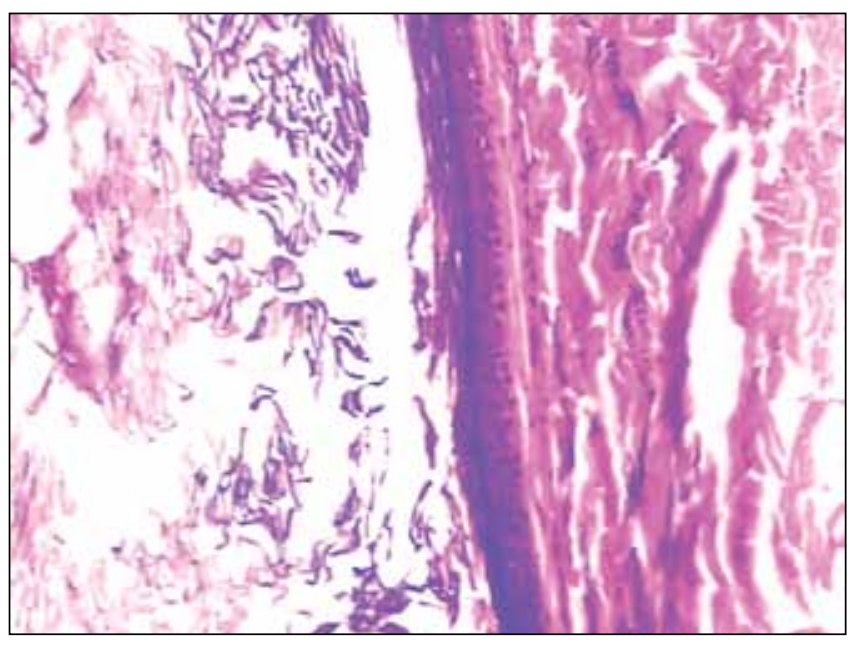

Figure 3: Pathological examination of the specimen showed the tumor contain desquamated epithelium and lamellated keratin-like material (H\&E, original magnification $\times 100)$. 
was performed in the prone position. After opening the dura, a well-encapsulated tumor was found attaching to the nerves of cauda equina and was then successfully dissected (Figure 2D). Pathological examination confirmed it to be an epidermoid tumor containing only desquamated epithelium and lamellated keratin-like material (Figure 3). After operation, the patient recovered well without any surgery-related complications or neurological deficit.

\section{DISCUSSION}

Epidermoid cysts are reported to be associated with trauma and surgery in bone, cartilage, and abdominal organs. It is well known that post-traumatic epidermoid cysts develop as a result of unintentional implantation of squamous epithelium into the deeper layers (1). There are also reports on the formation of spinal epidermoid cysts after lumbar puncture (6, $9,11)$. The etiology of such cysts has been partially confirmed via experimental direct skin implantation $(5,7)$. MRI is the diagnostic tool in these cases, and gives a rapid and accurate identification and evaluation of the extent of epidermoid tumors. These lesions, which primarily contain free fatty acids and very little cholesterol, normally exhibit a level of intensity similar to that of cerebrospinal fluid on T1-weighted images and a high signal intensity on the T2-weighted images, without contrast enhancement (3). However, a differential diagnosis should be made between congenital epidermoid tumors and our present case. Congenital epidermoid tumors are usually associated with spinal malformations, including spina bifida and other dysraphic states, and changes resulting from intraspinal erosive pressure, which can be observed on plain radiographs (13). Moreover, spinal epidermoid cysts generally appear as hypodense lesions on CT scans (12).

The major limitation of this report is that there was no spinal MRI examination on the patient before the first fracture operation 4 years ago. However, this drawback is partly compensated by a lumbar CT scan during the removal surgery of internal spinal fracture fixation devices 1 year later, which found no sign of tumor in the L1 segment. It should also be noted that this individual patient has no spinal malformation and concomitant cutaneous stigmata that are usually associated with congenital epidermoid and she did not suffer from progressively aggravating back pain radiating down left leg only until 3 years after the first spine surgery. Given her previous history of spine surgery and the perfect match between the site of primary operation and the site where the subsequent epidermoid tumor is located, we strongly propose that the epidermoid tumor in this case come into existence after the spinal fracture operation. This neoplasia might have resulted from the unintentional implantation of epidermal cells into the intradural space through the lacerated dura during the previous spinal fracture or surgical procedure. These dislocated cellular tissues then grow slowly and it is only until the mass is sufficiently large to compress the nerve roots when the patient will have the typical clinical manifestations $(2,8)$.

\section{CONCLUSION}

Most epidermoid cysts are congenital and fracture and operation are rarely regarded as the cause of epidermoid tumor. As far as we know, this is probably the first report on the development of a secondary spinal epidermoid cyst that is associated with previous lumbar burst fracture and/ or subsequent spinal surgery. Therefore, in patients with a history of spinal fracture operation, spinal epidermoid cysts should be taken into consideration if the low back pain and radiculopathy were refractory.

\section{REFERENCES}

1. Colreavy MP, O'Leary SJ, McKelvie PA: A post-traumatic nasal epidermoid: An endoscopic approach. American Journal of Rhinology 18(1): 53-55, 2004

2. Green AJ, Roberts DR, Swanson RA: Post-traumatic epidermoid cyst presenting with headache. Neurology 64(9): 1657,2005

3. Jeong IH, Lee JK, Moon KS, Kwak HJ, Joo SP, Kim TS, Kim JH, Kim SH: latrogenic intraspinal epidermoid tumor: Case report. Pediatric Neurosurgery 42(6): 395-398, 2006

4. Karadag D, Tuba Karagulle A, Erden A, Colpan E, Erden I, Caglar S, Erekul S: Post-traumatic intradiploic epidermoid cyst. A case report. J Neurosurg Sci 45(4): 224-227; discussion 7, 2001

5. Locatelli M, Alimehmeti R, Rampini P, Prada F: Intradiploic frontal epidermoid cyst in a patient with repeated head injuries: Is there a causative relationship? Acta Neurochir (Wien) 148(10): 1107-1110; discussion 10, 2006

6. Miyake S, Kobayashi N, Murai N, Kondoh T, Kohmura E: Acquired lumbar epidermoid cyst in an adult - Case report. Neurologia Medico-Chirurgica 45(5): 277-279, 2005

7. Oblu N, Wasserman L, Sandulescu G, Onofrei T: Experimental investigation of the origin of intraspinal epidermoid cysts. Acta Neurol Scand 43(1): 79-86, 1967

8. Park JC, Chung CK, Kim HJ: latrogenic spinal epidermoid tumor. A complication of spinal puncture in an adult. Clinical Neurology and Neurosurgery 105(4): 281-285, 2003

9. Per H, Kumandas S, Gumus H, Yikimaz A, Kurtsoy A: latrogenic epidermoid tumor: Late complication of lumbar puncture. Journal of Child Neurology 22(3): 332-336, 2007

10. Prat Acin R, Galeano I: Giant occipital intradiploic epidermoid cyst associated with iatrogenic puncture. Acta Neurochir (Wien) 150(4): 413-414, 2008

11. Refai D, Perrin RJ, Smyth MD: latrogenic intradural epidermoid cyst after lumbar puncture. Case illustration. J Neurosurg 106(4 Suppl): 322, 2007

12. Visciani $A$, Savoiardo $M$, Balestrini $M R$, Solero $C L$ : latrogenic intraspinal epidermoid tumor: Myelo-CT and MRI diagnosis. Neuroradiology 31(3): 273-275, 1989

13. Ziv ET, McComb JG, Krieger MD, Skaggs DL: latrogenic intraspinal epidermoid tumor - Two cases and a review of the literature. Spine 29(1): E15-E18, 2004 